\title{
Impact of Job Insecurity due to COVID-19 on the Psychological Wellbeing and Resiliency of Food Delivery Personnel
}

\author{
Aisha Sarwar \\ Department of Management and Social Sciences \\ Capital University of Science and Technology, \\ Islamabad, Pakistan \\ E-mail: aisha_sarwar02@hotmail.com
}

Usman Maqsood

Victoria University, Melbourne, Australia

E-mail: usmanmaqsood76@gmail.com

\author{
Bahaudin G. Mujtaba \\ (Corresponding Author) \\ Huizenga College of Business and Entrepreneurship \\ Nova Southeastern University \\ 3301 College Avenue \\ Fort Lauderdale, FL. 33314-7796. USA. \\ E-mail: mujtaba@nova.edu
}

Received: Nov. 8, 2020 Accepted: Dec. 7, 2020 Online published: Dec. 17, 2020

doi:10.5296/ijhrs.v11i1.18075 URL: https://doi.org/10.5296/ijhrs.v11i1.18075 


\section{Abstract}

This study examines when and why job insecurity due to COVID-19 leads to decreased well-being in hotel (restaurant) delivery personnel. It also examines resiliency as a moderator between job insecurity and employee anxiety. Data was collected in time lags from 253 respondents of food delivery personnel in hotel restaurants. The findings suggest that job insecurity due to COVID-19 decreased an employee's well-being via financial stress. Moreover, resiliency played a buffering role in mitigating the damaging impact of job insecurity on fanatical stress. Theoretical and practical implications are included in this paper.

COVID-19 is considered as most devastating and fatal diseases of this century since it is negatively impacting many industries, including hotels and restaurants. While some researchers have reflected upon the nature of this disease, the arrival of possible vaccine and economic outcomes, the employees' psychological outcomes are largely ignored areas of research. Hence, this study attempts to fill this gap by adding relevant knowledge to the field. This study contributes to literature in various ways. Firstly, this study proposes and measures employees' job insecurity due to infectious disease COVID-19 in hotels. Secondly, anxiety is measured as a mechanism to explain the relationship between perceived job insecurity and employees' psychological well-being.

Thirdly, this study proposes and empirically tests the factors which may decrease employees' well-being during the outbreak of a COVID-19 pandemic. Fourthly, this study examines employees' personality trait of resiliency as a buffering factor between job insecurity and employee anxiety. Finally, this research validates the conservation of resources theory in terms of external stressor and personal resource in the form of resiliency. Hence this study is a timely response against the current coronavirus pandemic to expand the scope in domain of mental health specifically among hotel employees to provide insights to practitioners. The objective of this paper is to examine the impact of job insecurity on mental health of hotel employees and to recommend a few avenues for practitioners to mitigate its devastating effects.

Keywords: job insecurity, COVID-19, financial stress, resiliency, psychological wellbeing

\section{Introduction}

The hospitality or service industry is one of the most vital sectors of the tourism industry that has been greatly impacted by the Covid-19 pandemic all around the globe (Akhtar, Akhtar, Usman, Moazzam \& Siddiqi, 2020). Due to popularity and common practice of fine dining as well as fast food outlets, this sector contributes to the global economy with hundreds of billion dollars. Unfortunately, the hospitality sector is most vulnerable to natural pandemics resulting in huge financial losses (Dube, Nhamo, \& Chikodzi, 2020). COVID-19 has emerged as a worst situation due to continuous rise in cases (Wang, Hu, Hu, Zhu, Liu, Zang, Lui, Zhao, Zhang, Zhang, Xiang, 2020). As of now, there are over 66 million cases of Covid-19 infections reported worldwide while 1.5 million people have died, and over 280,000 of these deaths are in the United States of America (Korman and Mujtaba, 2020).

The hotel industry is one of the worst affected in the COVID-19 pandemic due to demands of 
social distancing and travel bans which have caused deaths, layoffs and stress, while forcing many people to work from home (Gossling, Scot, \& Hall, 2020; Mujtaba, 2014; Cavico and Mujtaba, 2016; Mujtaba and Senathip, 2020a; Mujtaba and Senathip, 2020b; Tran, Tran, Nguyen, Mach, Phan, and Mujtaba, 2020). According to World Travel and Tourism Council, "50 million jobs globally are at risk" due to this pandemic. They further elaborated that the tourism industry is "already facing collapse" and hence is "in a fight for survival" because of the COVID-19 pandemic (Jiang \&Wen, 2020). Despite a growing number of studies on the spread of COVID-19, scarcity of research exists on the psychological impact of COVID-19 for employees and financial stress induced due to job risk (Cullen, Gulati, \& Kelly, 2020). Therefore, researchers should focus on employees of hospitality industry who are suffering most (Dube, Nhamo, \& Chikodzi, 2020). Due to strict lockdowns, many countries closed their restaurants under the stay at home order. This leaped hotels (restaurants are also called hotels in South Asia) into a crisis and the possibility of permanently closing if the pandemic continued for a long time (Dube, Nhamo, \& Chikodzi, 2020). This puts hotel employees to feel insecure about their jobs. The restaurant sector observed a $58 \%$ decrease in revenue from the period of March to May in the year 2020. (De Freitas \& Stedefeldt, 2020). Also, we know that $27.5 \%$ of hotel business owners stated that they will close business at some locations, and $16.1 \%$ said that they will close their business permanently (De Freitas \& Stedefeldt, 2020).

COVID-19 has created a crisis for most firms and employees due to quarantines and closures (Korman and Mujtaba, 2020; Mujtaba, Mesa, McGee, Moncada, 2020), but especially so for the retail and hospitality industry businesses like hotels and restaurants. For instance, hotels were closed due to a lockdown policy in the start of 2020. Restaurants were required to adopt a delivery service or to operate with significantly reduced capacities due to social distancing policy (Kim \& Lee, 2020; Iqbal, Khan, Mohmand, and Mujtaba, 2020). Hence, the hospitality industry future is in a catastrophe. According to some experts, many of the restaurants and hotels would not survive (Severson \& Yaffe - Bellany, 2020), which many trigger perceptions of job insecurity among hotel employees. The World Travel and Tourism Council (2020) declared that almost 75 million hospitality jobs are at risk now due to COVID-19 and these figures might also change if the virus continues to evolve in the future. The World Travel and Tourism Council (2020) also concluded about the spread of COVID-19 and its future effects based on the initial assessment of SARS in 2003. According to its initial assessment, tourist arrival may decrease between $1 \%-3 \%$ in 2020 and then the forecasted percentage increased to $3 \%-4 \%$. Tourism contributes to almost $10 \%$ towards the world's GDP and in creation of jobs (WEF, 2020), and now it is the worst impacted industry by the global pandemic. The duration and scope of this pandemic is not known. Countries depending on tourism are facing damaging and unprecedented economic setbacks. The impact of COVID-19 on the hospitality sector is a concern of the world, while decreasing revenues are putting hospitality employees' jobs at risk (Yousef, Zeqiri \& Dedaj). Massive job losses will occur in the hospitality sector of Asia if this pandemic continues (Kasare, 2020). Therefore, given the devastating impacts of COVID-19 on tourism and the hospitability industry, the hotel industry is also suffering. Hence, it is important to highlight each employee's emotional reactions in response to job insecurity due to COVID-19 to provide some practical solutions to overcome their stress. 
Financial stress amongst employees may make job insecurity a more agonizing experience, which in return intensifies financial stress (Choi, Heo, Cho, \& Lee, 2020). Huge unemployment persists in Pakistan (Ahmed, 2020), which may further trigger job insecurity perceptions in the COVID-19 pandemic. Although, hotels are offering food delivery services to homes through delivery personnel, locally referred to as "delivery boys" or "hotel riders" as they tend to be young working men riding motorcycles, but they may also be insecure about their jobs too as no one knows how long this pandemic will last. At the meantime, according to the World Health Organization and medical experts, the Covid-19 infection can be prevented by avoiding exposure to the virus and person-to-person contact while regularly washing one's hands with soap and hot water (Sohrabi, Alsafi, O'Neil, Kerwan, Al-Jabir, Agha, 2020). Job insecurity refers to an individual's perceptions about the fear of maintaining stability in job, the threat of losing job characteristics and ultimately job loss (Jiang \& Probst, 2016), and job insecurity increases during periods of economic downturn (Cheung, Gong \& Huang, 2016). Kein, Landsis Pierce and Ernest (2014) argued in their meta-analysis that future studies need to consider the psychological stressors induced by job insecurity. This study is a response to these researchers' calls to examine outcomes of jobs insecurity.

Researchers have realized that job insecurity has increased stress among workers regarding their health as well as their lives (Soelton, Amaelia \& Prasetyo, 2020). Job insecurity may also pose financial stress among employees (Choi, Heo, Cho, \& Lee, 2020). According to some experts (Mukhtar, 2020; Korman and Mujtaba, 2020), the COVID-19 outbreak has created numerous mental health issues in Asian countries like Pakistan. Pakistan is categorized among low- and middle-income nations ranking 152 out of 189 countries having a human development index value of 0.560.16 (Conceicao, 2019). Accordingly, Pakistan has faced many healthcare challenges and suffered over the past few decades due to such epidemics which put an economic burden on the poorest people of Pakistan (Morens, Folkers, $\&$ Fauci, 2004). The COVID-19 pandemic may put financial burdens and stress on people effecting their wellbeing (Colenda, Applegatee, Reifler \& Blazer, 2020). Hence, it is the need of time to explore antecedents of hotel delivery personnel wellbeing to find out the factors which may reduce employee's well-being specifically due to financial stress during the outbreak of COVID-19.

Job insecurity triggers stress but so far, few studies have considered this link (Choi, Heo, Cho, $\&$ Lee, 2020). And no study has considered this link during the COVID-19 pandemic. Accordingly, individuals experience more psychological and mental health related issues specifically in periods of epidemiological catastrophes (Li, Wang, Xue, Zhao, \& Zhu, 2020). Hence it can be argued that COVID-19 is highly dangerous for an employee's mental health and may trigger financial stress. Similarly, COVID-19 has caused many psychological problems amongst employees of Asia (Li, Wang, Xue, Zhao, \& Zhu, 2020), thereby making it more important to consider each employee's stress imposed by psychological stressors (Anasori, Bayighomog, \& Tanova, 2020). Employees that have a resiliency trait have far fewer chances of experiencing stress due to job insecurity (Behnke, Rojas, Karabatskiakis \& Kolassa, 2020). 


\section{Literature Review}

\section{Job insecurity and employee wellbeing}

Generally, people are motivated to engage in social interactions, However the COVID-19 pandemic has led people to live in the "new normal", which has forced them to social distance (Serverson \& Yaffe-Bellany, 2020). Recommendations of staying at home have changed employee's perceptions about foods they purchase. Most people are housebound except essential workers (Goddard, 2020). Individuals perceive that they are more vulnerable to unemployment (Goddard, 2020). Restaurants and hotels also felt the same changes as eating places are closed thereby increasing home delivery and take out options.

Psychological wellbeing, which refers to a good state of psychological happiness or security (Ryff \& Keyes, 1995), has different dimensions including personal growth, positive relations, autonomy, self-acceptance, and environment mastery. The concept of psychological well-being originated from western culture; however, this concept has already been applied in collectivistic cultures of Asia (Markus \& Kitayama, 1998). Employee well-being is necessary if organizations want to be sustainably healthy and successful (Wilson, Dejoy, Vandenberg, Richardson \& Megrath, 2004). Due to its significance, an employee's well-being has received intensified scholarly attention (Iies, Puut, \& Aw, 2015). Perceived job insecurity is a critical employment related stressor amongst contemporary employees (De Wite, Vander, Elst, \& De Cuyper, 2015). Job insecurity is a stressor leading to negative outcomes specifically for health and well-being of employees such as psychological wellbeing, satisfaction and burnout (De Wite, Vander, Elst, \& De Cuyper, 2015). A stressor like job insecurity is considered a psychological risk which may also cause poor relations with others (Leks, Jain \& Organization, 2010).

Previous epidemics in history gave indications that such stressors effect psychological responses of employees (Ripp et al., 2020). In addition, job insecurity is linked with unemployment that further impairs employees' health and their wellbeing (De Wittie, Vander, Elst, \& De Cuyper, 2016; McKee-Ryan, Song, Wanberg \& Kinicki, 2005). Researchers have put emphasis on maintenance of employee's psychological health to fulfill numerous human needs like self-determination, survival, and relatedness (Van dan Broeck, Vanseteenkiste, De Wittie \& Lens, 2008) Hence, job insecurity means frustration of employees' fundamental human needs and this frustration may lead to impairment of their psychological wellbeing. As such, we propose the following hypothesis:

Hypothesis 1: Job insecurity due to COVID-19 has a negative relationship with employee's psychological wellbeing.

\section{Mediating the role of financial stress}

Financial stress is a money worry (Starrin, Aslund, \& Nilson, 2009); and money worry is economic pressure, stress, strain and hardship (Heo, Cho. \& Lee, 2017). In simpler words, financial stress refers to the combination of an emotional response as well as a physical one that is induced by certain stimulus like urgent payment (Grable, Heo \& Rabbani, 2015). Epidemic outbreaks may result in psychological distress (Moccia et al., 2020). Employees 
face stress when they are not able to effectively handle stressful situations, especially during pandemics (Chew et al., 2020). An employee's wellbeing is being threatened by the COVID-19 pandemic (Zhang, Wang, Raunch, \& Wei, 2020). Hence this study is a timely attempt to consider the wellbeing of hotel riders (delivery personnel). Furthermore, in periods of global pandemic, financial stress of hotel riders may increase because of the increased numbers of victims and risk of COVID-19 (Rubin \& Wessely, 2020). Employees experiencing financial stress perceive such situations as threatening (Hobfoll, 1989). Therefore, increased employee financial stress and resource investment of employees without replenishing them may lead employees to experience a decrease in wellbeing (Halbesleben, Neveu, Paustain-Underdahl \& Westman 2014). Conservation of resources (COR) theory (Hobfoll, 1989) claims that individuals try to gain and maintain valued resources. According to the resource loss principle of the COR theory, individuals experiencing threatening situations like job insecurity may lose resources by seeing a situation as more threatening and developing financial stress which in turn may lead to a decrease in psychological wellbeing among employees. Hotel employees experiencing a hostile situation in this pandemic like job insecurity may lose their cognitive as well as emotional resources which results in financial stress. Job insecurity diminishes employees' resources as a result, and resource deficient employees experience reduced wellbeing. As such, we propose the following hypothesis:

Hypothesis 2: Financial stress mediates the relationship between perceived risk of COVID-19 and employee's wellbeing.

Resiliency is an individual's positive adaptations as well as coping mechanisms when one is facing risks and adversities (Masten \& Reed, 2002), which makes it possible for an individual to survive in the taxing environment (Luthans, Avlio, Avey \& Norman, 2007). Resiliency may act as a moderator between an employees' stressors and certain psychological outcomes (Kimura, Bande, \& Feranadez-Ferrin, 2018; Sarwar, Naseer, \& Zhong, 2020). Furthermore, a secondary resource loss assumption of the COR theory claims that individuals having more resources tend to better cope with stressful environments and situations. Therefore, this study considers resiliency as an interpersonal resource to protect employees against devastating effects of stressors (Hobfoll, Halbesleben, Neveu, \& Westman, 2018). In accordance with this theory, it is believed that resiliency may act as a personal coping resource to help protect employees from decreased wellbeing. This study contributes to literature by considering resiliency as a personal resource in buffering the effects of job insecurity and financial stress relationship in the hospitality sector.

Hypothesis 3: Resiliency moderates the relationship between job insecurity and employee financial stress such that this positive relationship is stronger when resiliency is low.

\section{Methodology}

Data was collected from hotel delivery personnel who are serving customers during the current pandemic. Data was collected at three-time intervals from 25th April 2020 to 25th May 2020. On the 25th of February 2020, the first case of COVID-19 was identified in Pakistan (Waris, Khan, Ali, \& Baset, 2020). This disease quickly spreads to the whole country due to its contagious nature and deficiencies of the Pakistani healthcare system 
(Mukhtar, 2020). So far, more than 300,000 cases have been reported in Pakistan and it is continuing to rise fast. Data was collected from employees providing delivery services. Convenience sampling was used to collect data. Data for job insecurity and resiliency was collected at T1. While employee financial stress was measured at T2 after a gap of seven days and employees' psychological wellbeing was measured at T3 after another seven-day gap. Employees were accessed through email. A cover letter was attached with each survey to highlight the study's purpose and that their responses will remain confidential. At the time 500 surveys were sent out. We received 410 surveys back. 410 surveys were circulated again, and we received 305 surveys; then 305 surveys were circulated again, and we received 253 questionnaires back with a response rate of $50.6 \%$.

\section{Measures}

Surveys were conducted in English, as it is the official language of Pakistan and previous studies also used the English language to administer surveys as recently and found no concern in this regard (Sarwar, Bashir, \&Karim Khan, 2019; Sarwar \& Muhammad, 2020; Sarwar, et al., 2020). Items for job insecurity, anxiety and psychological wellbeing were measured on a five-point Likert scale with " $1=$ Strongly Disagree" to " $5=$ Strongly Agree". Resiliency was measured on five-point Likert scale with a range of " $1=$ Not at all," to " $5=$ Most of the time."

Job insecurity. Job insecurity was measured at T1 by adapting the 4 items scale developed by De Witte (2000). COVID-19 was added at the end of each item. The original item was "I am sure that I will not be able to keep my job" and it was replaced with "I am sure I will not be able to keep my job due to COVID-19." Items are shown in Table 2.

Resilience. Resiliency trait was measured by adopting a six-item scale from Psychological Capital (Luthans, Avey, Avolio, Norman \& Combs, 2006). Sample items are "I enjoy dealing with new and unusual events" and "I restore my normal mood quickly after unpleasant events".

Financial Stress. Financial stress (affective response) was measured by adopting an eight-item scale. Sample items included "I feel depressed because of my financial situation."

Psychological Wellbeing. Psychological wellbeing was measured by adopting a six-item scale (Zheng, Zhu, Zhao, and Zhang, 2015). Sample items are "I feel I have grown as a person" and "I handle daily affairs well."

\section{Results}

Table 1 represents demographic characteristics with $74.3 \%$ male and $25.7 \%$ female respondents, $42.3 \%$ belonged to age 25 and below, 33.2\% were between the ages of 26-35, $17 \%$ were between the ages $36-45$, and $7.5 \%$ where 46 and above. Regarding education, $19.8 \%$ were having qualifications of intermediate, $66.8 \%$ had qualification of bachelors, and $13.4 \%$ had qualifications of Master's degrees. PLS-SEM was used to evaluate the measurement model first and later structural models (Hair, Risher, Sarstedt, \& Ringle, 2019). PSL-SEM was employed to analyze the data because it is a powerful tool to examine 
prediction-orientation of constructs. Out sample prediction technique was introduced recently by Shmueli in 2019.

Table 1. Demographics

\begin{tabular}{lccc}
\hline Demographic Characteristics & Frequency & Percent & $\begin{array}{c}\text { Cumulative } \\
\text { Percent }\end{array}$ \\
\hline Gender & 188 & 74.3 & 74.3 \\
Males & 65 & 25.7 & 100.0 \\
Females & 101 & 42.3 & \\
Age & 84 & 33.2 & 42.3 \\
$\mathbf{2 5}$ \& below & 43 & 17.0 & 75.5 \\
$\mathbf{2 6}$-35 & 19 & 7.5 & 92.5 \\
$\mathbf{3 6}$-45 & & & 100.0 \\
$\mathbf{4 6}$ \& above & 50 & 19.8 & 19.8 \\
Education & 169 & 66.8 & 86.6 \\
Intermediate & 34 & 13.4 & 100.0 \\
Bachelors & & & \\
Masters & & & \\
\hline
\end{tabular}

Method of Analysis

Basic appeal of PLS-SEM is that this method allows researchers for estimation of complex models having many constructs, indicators and structural paths. Furthermore, PLS-SEM is a causal predictive approach with emphasis on prediction while estimating the statistical models (Hair et. al, 2019). This technique of prediction overcomes the apparent dichotomy in explanation (emphasized in academic research) and prediction (basis for developing managerial implications (Hair et. al, 2019). Further, researchers are recommended to apply PLS predict in studies of PLS-SEM to evaluate predictive power (Shmueli et al., 2019), specifically to draw conclusions for managerial implications. Further, CB-SEM executed by AMOS uses covariance matrix and considers common variance to estimate model parameters. While, PLS-SEM is variance-based because it estimates parameters by using total variance (Rigdon, Becker, \& Sarstedt, 2017; Memon, Cheah, Ramayah, Ting, Chuah, \& Cham, 2019).

Once considering PLS-SEM, data is analyzed for measurement model and structural model. In measurement model reliability and validity are considered. In structural model hypothesis testing is made. Hence, this study first considers measurement model, following the structural model, moderation analysis, and then predictive relevance are presented.

\section{Measurement model}

The measurement model assesses the reliability and validity of constructs (Hair, Risher. Sarstedt, \& Ringle, 2019). Composite reliability was assessed to check reliability. Two items (R2, R3) of resiliency were having low loadings than standard value of 0.7 (Gefen, Straub. \& Boudreau 2000). Therefore, measurement was reassessed after deleting these two items. Minimum value of composite reliability is 0.839 which was greater than standard value of 0.70 (Gefen, Straub. \& Boudreau 2000). Average variance extracted (AVE) was assessed for 


\section{Macrothink}

International Journal of Human Resource Studies ISSN 2162-3058 2021, Vol. 11, No. 1

convergent validity (Gefen, Straub \& Boudreau 2000.). Findings suggest that values of AVE were greater than the minimum threshold value that was greater than 0.50 . Table 2 shows items loading.

Table 2. Reliability and Validity

\begin{tabular}{|c|c|c|c|c|}
\hline \multicolumn{2}{|c|}{ Measures } & $\mathbf{O L}$ & $\mathrm{CR}$ & AVE \\
\hline \multicolumn{3}{|c|}{ Job Insecurity } & 0.879 & 0.647 \\
\hline JI1 & $\begin{array}{l}\text { "I am sure that I will not be able to keep my job due to } \\
\text { COVID-19." }\end{array}$ & 0.706 & & \\
\hline JI2 & $\begin{array}{l}\text { "There is a risk that I will lose my present job in the near future } \\
\text { due to COVID-19." }\end{array}$ & 0.876 & & \\
\hline JI3 & "I feel uncertain about the future of my job due to COVID-19." & 0.748 & & \\
\hline JI4 & $\begin{array}{l}\text { "I think that I will lose my job in the near future due to } \\
\text { COVID-19." }\end{array}$ & 0.873 & & \\
\hline \multicolumn{3}{|c|}{ Anxiety } & 0.917 & 0.611 \\
\hline FS1 & "I feel depressed because of my financial situation." & 0.772 & & \\
\hline FS 2 & "I feel sad because of my financial situation." & 0.756 & & \\
\hline FS 3 & "I am fearful because of my financial situation." & 0.808 & & \\
\hline FS 4 & "I feel anxious because of my financial situation." & 0.786 & & \\
\hline FS 5 & "I worry a lot because of my financial situation." & 0.806 & & \\
\hline FS 6 & "I am easily irritated because of my financial situation." & 0.781 & & \\
\hline FS 7 & "I feel emotionally drained because of my financial situation." & 0.763 & & \\
\hline \multicolumn{3}{|c|}{ Well Being } & 0.886 & 0.564 \\
\hline WB1 & "I feel I have grown as a person." & 0.779 & & \\
\hline WB2 & "I handle daily affairs well." & 0.798 & & \\
\hline WB3 & "I generally feel good about myself, and I'm confident." & 0.757 & & \\
\hline WB4 & "People think I am willing to give and to share my time with others" & 0.734 & & \\
\hline WB5 & "I am good at making flexible timetables for my work." & 0.735 & & \\
\hline WB6 & $\begin{array}{l}\text { "I love having deep conversations with family and friends so that we can } \\
\text { better understand each other." }\end{array}$ & 0.701 & & \\
\hline \multicolumn{3}{|c|}{ Resiliency } & 0.839 & 0.588 \\
\hline R1 & "I restore my normal mood quickly after unpleasant events." & 0.655 & & \\
\hline R4 & "I prefer following more than one route to achieve goals." & 0.826 & & \\
\hline R5 & "I prefer work that is both new and challenging." & 0.825 & & \\
\hline R6 & $\begin{array}{l}\text { "I overcome feelings of anger that I may have toward a particular } \\
\text { person" }\end{array}$ & 0.861 & & \\
\hline \multicolumn{5}{|c|}{ OL $=$ Outer Loadings, $\mathrm{CR}=$ Composite Reliability, $\mathrm{AVE}=$ Average Variance Extracted } \\
\hline
\end{tabular}

Heterotrait-monotrait ratio (HTMT) criteria was used to assess discriminant validity (Henseler, Ringle \& Sarstedt, 2015) and it is presented in table 3. HTMT value is acceptable 
if lower than 0.9 .

Table 3. Discriminant Validity of Measurement Model- Heterotrait-Monotrait Ratio (HTMT) of Correlations

\begin{tabular}{lllll}
\hline Constructs & FS & JI & R & WB \\
\hline FS & & & \\
JI & 0.424 & & & \\
R & 0.536 & 0.292 & & \\
WB & 0.499 & 0.502 & 0.471 & \\
\hline
\end{tabular}

\section{Structural model}

T-values, out sample prediction, effect sizes $\mathrm{F}^{2}$, confident of determination $\left(\mathrm{R}^{2}\right)$ and predictive relevance $\mathrm{Q}^{2}$ are evaluated through the structural model constructs (Hair, Risher. Sarstedt, \& Ringle, 2019). The 5000 bootstrapping procedure was used to assess t-values constructs (Hair, Risher. Sarstedt, \& Ringle, 2019). Impact of job insecurity on an employee's wellbeing $(\mathrm{H} 1)$ was accepted $(\mathrm{B}=-0.396, \mathrm{p}=0.000)$.

Table 4. Analysis of Structural Model (Hypotheses testing)

\begin{tabular}{cccccccccc}
\hline $\begin{array}{c}\text { Hypot } \\
\text { hesis }\end{array}$ & $\begin{array}{c}\text { Relationship } \\
\text { S }\end{array}$ & $\boldsymbol{\beta}$ & $\mathbf{S E}$ & $\begin{array}{c}\text { t-valu } \\
\text { es }\end{array}$ & $\begin{array}{l}\mathbf{P} \\
\text { values }\end{array}$ & $\mathbf{f}^{2}$ & $\mathbf{R}^{2}$ & $\mathbf{Q}^{2}$ & Decision \\
\hline H1 & $\mathrm{JI} \rightarrow \mathrm{WB}$ & -0.396 & 0.047 & 8.481 & 0.000 & 0.106 & 0.287 & 0.147 & Accepted
\end{tabular}

Mediation and moderation were assessed by evaluating confidence intervals through the approach of Preacher and Hayes (2008) with 5000 bootstrapping. Table 5 demonstrates that H2 was accepted at confidence intervals that have no zero (Preacher \& Hayes, 2008).

Table 5. Analysis of Mediation

\begin{tabular}{|c|c|c|c|c|c|c|c|c|}
\hline Hypothesis & Relationships & B & SE & t-values & $\begin{array}{l}\mathbf{P} \\
\text { values }\end{array}$ & & CI.95 & Decision \\
\hline & & & & & & $2.50 \%$ & $97.50 \%$ & \\
\hline H2 & $\mathrm{JI} \rightarrow \mathrm{FS} \rightarrow \mathrm{WB}$ & -0.100 & 0.035 & 2.886 & 0.004 & -0.178 & -0.043 & Accepted \\
\hline
\end{tabular}

Resiliency is considered a moderator between job insecurity and an employee's financial stress moderation. Results are represented in table 6. Moderation effect was investigated by multiplying job insecurity (predictor) and resiliency (moderator) to create an interaction term (Henseler \& Fassott, 2010). The impact of the predicting variable was assessed on criterion variable by employing 5000 bootstrapping procedure. Additionally, moderator and interaction term effect on criterion variable was standardized path coefficient with $-0.162(\mathrm{p}=0.010, \mathrm{t}=$ 2.561). Moreover, confidence intervals did not show zero $(-0.288,-0.077)$, confirming the moderation effect. Hence it can be concluded that resiliency moderates the relationship between job insecurity and stress. 
Table 6. Moderation Analysis

\begin{tabular}{llllllrrrr}
\hline Hypothesis & Relationship & B & SE & \multicolumn{1}{l}{$\begin{array}{l}\text { t-valu } \\
\text { es }\end{array}$} & $\begin{array}{l}\text { P } \\
\text { values }\end{array}$ & & CI.95 & Decision \\
& S & & & & & & \\
\hline \multirow{3}{*}{ H3 } & & & & & & $2.50 \%$ & $97.50 \%$ & \\
& JI -> FS & 0.335 & 0.066 & 5.085 & 0.000 & 0.186 & 0.444 & \\
& R -> FS & -0.321 & 0.049 & 6.542 & 0.000 & -0.423 & -0.233 & \\
& Interaction & -0.162 & 0.063 & 2.561 & 0.010 & -0.288 & -0.077 & Accept \\
& term-> FS & & & & & & & \\
\hline
\end{tabular}

As per our findings, H3 was supported. Moderation results are further shown in figure 2.

Time-1

Time-2

Time-3

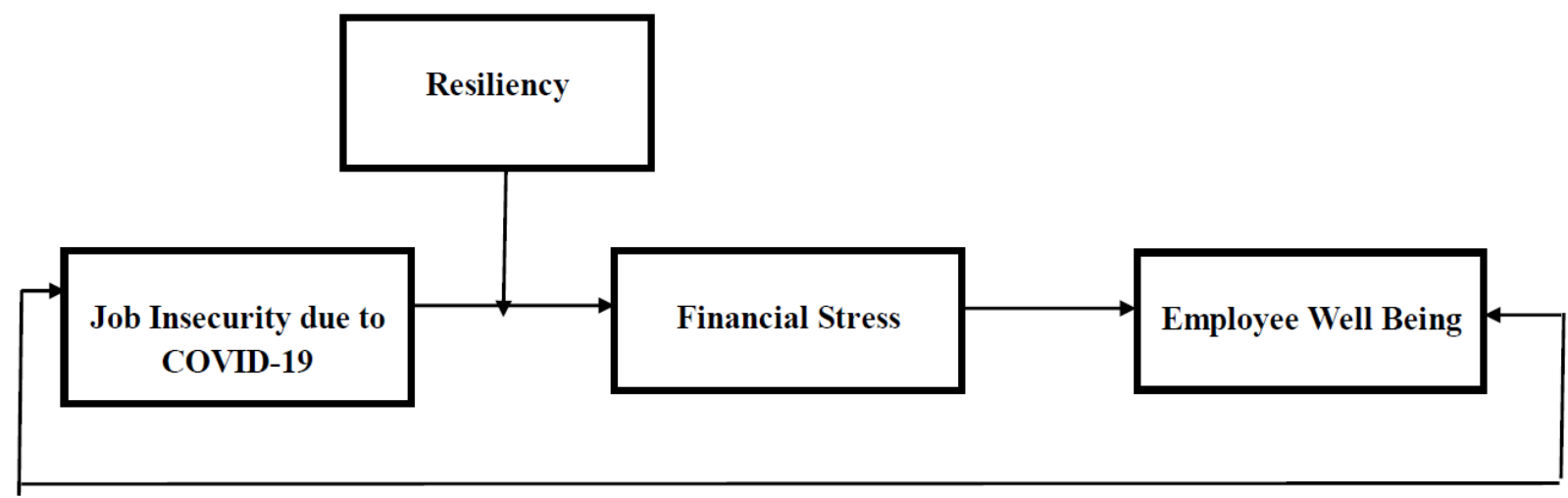

Figure 1. Job Insecurity effect Employee Well-being through financial stress (financial anxiety) and Resiliency as a moderator

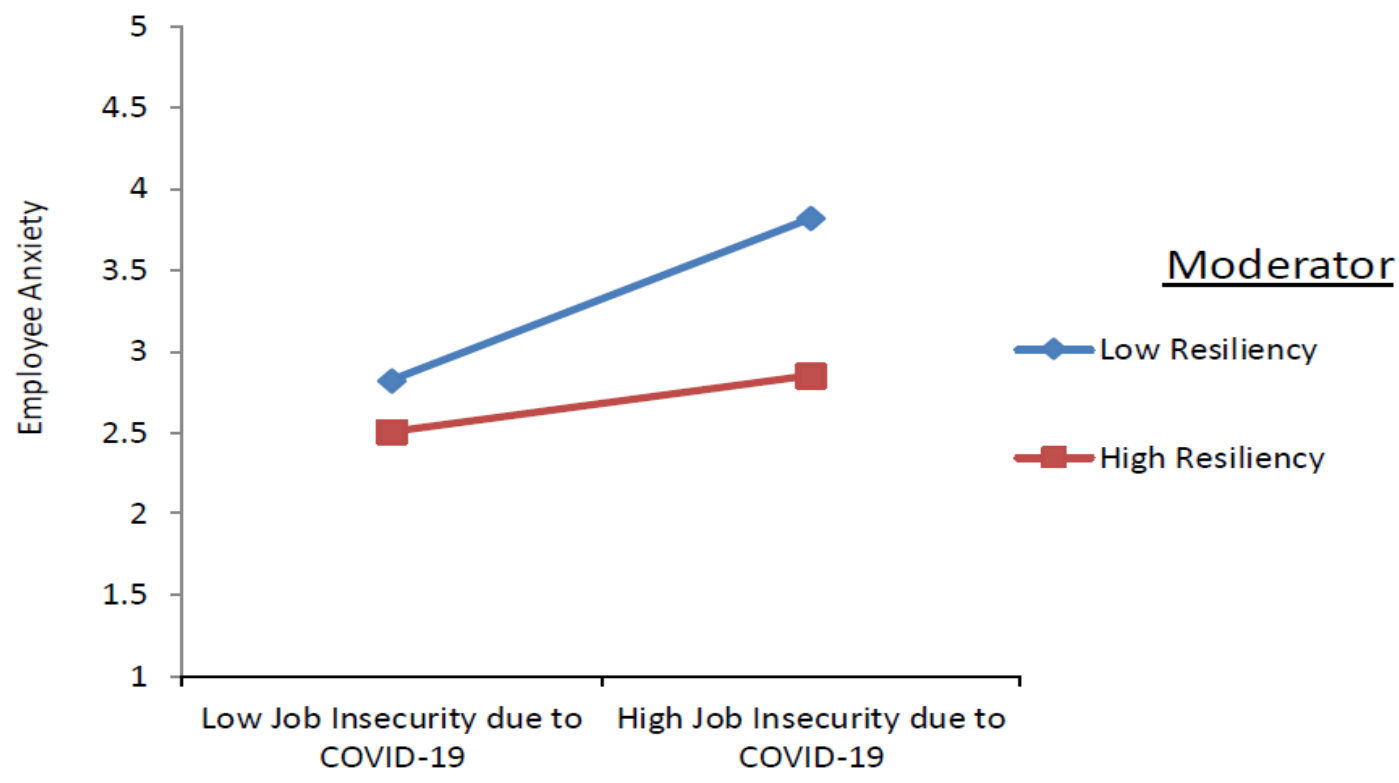

Figure 2. Interactive Effects of Job Insecurity due to COVID-19 and Resiliency on Employee Financial stress 


\section{Macrothink}

International Journal of Human Resource Studies

ISSN 2162-3058

2021, Vol. 11, No. 1

Prediction orientation through $\mathrm{Q}^{2}$ and $\mathrm{R}^{2}$ was revaluated through PLS-SEM. Table 4 presented these values. Predictive relevance is shown through values of $Q^{2}$ as well as $R^{2}$. Furthermore, the value of $\mathrm{f}^{2}$ was 0.106. According to Cohen (1988), values like 0.02, 0.15 and 0.35 of $\mathrm{f}^{2}$ are considered small, medium, and large. Similarly, out sample prediction technique is recommended to conduct prediction analysis. Furthermore, sample prediction was assessed through PSL-Predict (Shmuli et al, 2019) and table 5 showed these results.

Table 7. Out Sample Prediction

\section{PLS-MAE LM-MAE}

\begin{tabular}{lcc}
\hline FS1 & 0.664 & 0.674 \\
FS 2 & 0.687 & 0.701 \\
FS 3 & 0.825 & 0.844 \\
FS 4 & 0.731 & 0.761 \\
FS 5 & 0.880 & 0.900 \\
FS 6 & 0.937 & 0.935 \\
FS 7 & 0.847 & 0.849 \\
WB1 & 0.935 & 0.944 \\
WB2 & 0.954 & 0.955 \\
WB3 & 0.770 & 0.786 \\
WB4 & 0.889 & 0.897 \\
WB5 & 0.898 & 0.903 \\
WB6 & 0.940 & 0.932 \\
\hline
\end{tabular}

\section{Discussion}

The risk of COVID-19 is a problem for hotel workers because the hotel industry is heavily impacted. However, some workers continue to perform their duties as hotels are delivering food to homes. Hence, hotel employees are anxious about their future. This study shows that hotel delivery employees are developing perceptions of job insecurity due to COVID-19 and experience decreased wellbeing with regards to their happiness and job security. The results are consistent with the previous literature where authors argued that job insecurity is a threat to workers, and it often leads to the employees' poor wellbeing (De Witte et al., 2016). According to Charkhabi (2018), job insecurity may affect employees' psychological wellbeing significantly. Previous studies revealed that if employees are anxious about their job's future, they may report psychological strains (Urbanaviciute, Lazaukaite-Zabielske, Vander Elst, De Witte, 2018). Furthermore, COR theory (Hobfoll, 1989) claims that employees experiencing loss of cognitive and emotional resources due to stressors may experience decreased wellbeing.

Findings of this study suggest that financial stress among employees mediates the relationship between job insecurity and employee wellbeing. The results can be justified through literature where anxiety and depression cause impaired wellbeing of employees' and can cause an increase in depression and stress during outbreaks of epidemics (Sun, Wu, Qu, 
Lu \& Wang, 2014). Results can also be justified through literature reporting that employees working during a pandemic are more prone to develop mental health and psychiatric issues (Hamouche, 2020). Moreover, employees of developing countries experience more financial stress (Conceicao, 2019).

The results showed that employees having resiliency trait experienced less stress due to job insecurity. Results can be justified by employing the COR theory (Hobfoll 2001) that personal resource of employees in the form of resiliency act as a buffering resource in lessening the devastating effects of perceived job insecurity. The COR theory postulates that individuals with more reserves of resources are better in protecting themselves against stressors (Hobfoll, 1989). Furthermore, individuals with more sources can better absorb their resource loss because they have more resources to invest in stressful situations (Hobfoll, 2002), due to good protection mechanisms.

\section{Theoretical Implications}

This study contributes to literature in various ways; firstly, this study proposed and measured hotel food delivery job insecurity due to the infectious disease COVID-19. Secondly, financial stress is measured as a mechanism to explain the relationship between perceived job insecurity and employees' psychological wellbeing. Thirdly, this study proposed and empirically tested the factors which may decrease employees' wellbeing during the outbreak of a pandemic like COVID-19. Fourthly, this study examined employees' personality trait of resiliency as a buffering factor between job insecurity and employee financial stress. Hence, this study is a timely response against the current global situation to expand the scope in domain of mental health specifically among hotel delivery personnel.

\section{Practical Implications}

This study offers significant practical recommendations to hotel management. Our findings suggest that financial stress triggered by perceived job insecurity may reduce an employee's wellbeing. Slaski and Cartwright (2003) found in their study the benefits of emotional intelligence and stress related training of employees to decrease their anxiety. The findings offer managers with valuable vision that hotels may provide employees with training as well as development programs to manage each employee's emotions during the outbreak of COVID-19. Hotels may also take advice from psychological therapist to help their employees in this tough time of the COVID-19 pandemic (Korman and Mujtaba, 2020). Findings also reveal that employees with resiliency traits experience less anxiety due to perceived risk of job insecurity. The need for resources of mental health support (like spiritual care, employee assistance programs and psychiatry services) is evident. Restaurants and hotels providing home delivery and takeout options should follow proper operating procedures and properly train all their employees for delivery of all services (Iqbal, Khan, Mohmand, and Mujtaba, 2020). Employees who carry the delivery to customers and receivers of food must follow strict hygiene practices regarding safe reception, food handling, as well as storage or heating guidelines suggested by sanitary legislation. Employees who are not aware of food safety training should learn about and practice good hygiene as well as proper sanitation. Hotel employees need to adopt safe practices to receive, store, produce, pack, transport, and deliver 
meals. Hotels need to ensure a healthy working environment for all employees including managers, kitchen workers and delivery drivers.

Hotels need to ensure safety of food production as well as the health of their stakeholders no matter whether they are kitchen workers, delivery personnel, or customers to increase their wellbeing. Many restaurants have implemented a safe delivery system to continue their business and ensure social isolation. This has forced employees of hotels, owners, and their workers to reinvent their roles to adopt this new approach. Customers purchase and order good products they think are safe and they may judge this through their delivery experience and specifics of packing.

\section{Limitations and Research Directions}

The current study acknowledges several limitations. This study collected data from hotels at different time intervals. However, it is not considered as longitudinal research design. Future researchers may be benefited by employing "cross lagged panel design". This study considered how and when job insecurity perceptions during this pandemic may decrease employee's wellbeing. Future researchers may consider other mechanisms as well as boundary conditions of job insecurity. Examining these might help practitioners to design and implement effective intervention programs for decreasing job insecurity perceptions.

This study investigated financial stress as a mediator. Future researchers may consider other meditators like emotional exhaustion, anger, and poor sleep patterns of employees. This study used resiliency as a personal trait and the role it played as a protective resource which alleviated the devastating effects of job insecurity and financial stress. Future researchers may consider other resources like self-efficacy, psychological capital, and optimism that may help in reducing the negative effects of job insecurity.

\section{Conclusion}

The hotel industry is highly impacted due to restrictions in air travel and government mandated quarantine closures. The COVID-19 pandemic has no known duration, thereby making hotel employees more depressed due to closures and other safety measures. Some hotels are now serving home deliveries of food due to this pandemic to stay in business, avoid layoffs, and to keep their employees working productively. Hotels and restaurants should continue to adapt and take care of their employees with kindness as they are risking their lives when delivering food to homes of customers. Hotels and restaurants should ensure the safety of their employees to decrease job insecurities, increase commitment, and gain new customers in their local communities.

\section{Funding}

Current Research did not include formal financial funding and/or support. The author(s) declare that preparation of this manuscript was not supported by any external funding and is mere effort of the authors included. 


\section{References}

Ahmed, B. (2020). Inflation and Unemployment in Pakistan: An Empirical Analysis. Pakistan Social Sciences Review, 4(2), 306-318. https://doi.org/10.35484/pssr.2020(4-II)25

Akhtar, N., Akhtar, M. N., Usman, M., Moazzam, A., \& Siddiqi, U. I. (2020). COVID-19 restrictions and consumers' psychological reactance toward offline shopping freedom restoration. The Service Industries Journal, 40, 13-14, 891-913. https://doi.org/10.1080/02642069.2020.1790535

Anasori, E., Bayighomog, S. W., \& Tanova, C. (2020). Workplace bullying, psychological distress, resilience, mindfulness, and emotional exhaustion. The Service Industries Journal, 40(1-2), 65-89. https://doi.org/10.1080/02642069.2019.1589456

Behnke, A., Rojas, R., Karabatsiakis, A., \& Kolassa, I.-T. (2020). Childhood maltreatment compromises resilience against occupational trauma exposure: a retrospective study among emergency medical service personnel. Child abuse \& neglect, 99, 104248. https://doi.org/10.1016/j.chiabu.2019.104248

Cavico, F. J., \& Mujtaba, B. G. (2016). Developing a Legal, Ethical, and Socially Responsible Mindset for Sustainable Leadership. ILEAD Academy: Florida.

Charkhabi, M. (2018). Do cognitive appraisals moderate the link between qualitative job insecurity and psychological-behavioral well-being? International Journal of Workplace Health Management, 11(6), 424-441. https://doi.org/10.1108/IJWHM-01-2018-0008

Cheung, S. Y., Gong, Y., \& Huang, J.-C. (2016). Emotional intelligence, job insecurity, and psychological strain among real estate agents: A test of mediation and moderation models. The International Journal of Human Resource Management, 27(22), 2673-2694. https://doi.org/10.1080/09585192.2015.1091369

Chew, N. W., Lee, G. K., Tan, B. Y., Jing, M., Goh, Y., Ngiam, N. J., \& Shanmugam, G. N. (2020). A multinational, multicentre study on the psychological outcomes and associated physical symptoms amongst healthcare workers during COVID-19 outbreak. Brain, behavior, and immunity. https://doi.org/10.1016/j.bbi.2020.04.049

Choi, S. L., Heo, W., Cho, S. H., \& Lee, P. (2020). The links between job insecurity, financial well-being and financial stress: A moderated mediation model. International Journal of Consumer Studies. https://doi.org/10.1111/ijcs.12571

Cohen, J. (1988). The t test for means. Statistical power analysis for the behavioural sciences: Hillsdale, NJ: Lawrence Erlbaum Associates.

Colenda, C. C., Applegate, W. B., Reifler, B. V., \& Blazer, D. G. (2020). COVID-19: Financial Stress Test for Academic Medical Centers. Academic Medicine. https://doi.org/10.1097/ACM.0000000000003418

Conceição, P. (2019). Human Development Report 2019: Beyond Income, Beyond Averages, Beyond Today: Inequalities in Human Development in the 21st Century: United Nations 
Development Programme.

Cullen, W., Gulati, G., \& Kelly, B. (2020). Mental health in the Covid-19 pandemic. QJM: An International Journal of Medicine, 113(5), 311-312. https://doi.org/10.1093/qjmed/hcaa110

de Freitas, R. S. G., \& Stedefeldt, E. (2020). COVID-19 pandemic underlines the need to build resilience in commercial restaurants' food safety. Food Research International. https://doi.org/10.1016/j.foodres.2020.109472

De Witte, H., Pienaar, J., \& De Cuyper, N. (2016). Review of 30 years of longitudinal studies on the association between job insecurity and health and well-being: Is there causal evidence? Australian Psychologist, 51(1), 18-31. https://doi.org/10.1111/ap.12176

De Witte, H., Vander Elst, T., \& De Cuyper, N. (2015). Job insecurity, health and well-being $\begin{array}{llll}\text { Sustainable lives } \quad \text { working } \quad \text { 109-128): } & \text { Springer. }\end{array}$ https://doi.org/10.1007/978-94-017-9798-6_7

Dube, K., Nhamo, G., \& Chikodzi, D. (2020). COVID-19 cripples global restaurant and hospitality industry. Current Issues in Tourism, 1-4. https://doi.org/10.1080/13683500.2020.1773416

Gefen, D., Straub, D., \& Boudreau, M.-C. (2000). Structural equation modeling and regression: Guidelines for research practice. Communications of the association for information systems, 4(1), 7. https://doi.org/10.17705/1CAIS.00407

Goddard, E. (2020). The impact of COVID-19 on food retail and food service in Canada: Preliminary assessment. Canadian Journal of Agricultural Economics/Revue canadienne d'agroeconomie. https://doi.org/10.1111/cjag.12243

Gössling, S., Scott, D., \& Hall, C. M. (2020). Pandemics, tourism and global change: a rapid assessment of COVID-19. Journal of Sustainable Tourism, 1-20. https://doi.org/10.1080/09669582.2020.1758708

Grable, J., Heo, W., \& Rabbani, A. (2015). Financial anxiety, physiological arousal, and planning intention. Journal of Financial Therapy, 5(2), 2. https://doi.org/10.4148/1944-9771.1083

Hair, J. F., Risher, J. J., Sarstedt, M., \& Ringle, C. M. (2019). When to use and how to report the results of PLS-SEM. European Business Review, 31(1), pp. 2-24. https://doi.org/10.1108/EBR-11-2018-0203

Halbesleben, J. R., Neveu, J.-P., Paustian-Underdahl, S. C., \& Westman, M. (2014). Getting to the "COR" understanding the role of resources in conservation of resources theory. Journal of Management, 40(5), 1334-1364. https://doi.org/10.1177/0149206314527130

Hamouche, S. (2020). COVID-19 and employees' mental health: stressors, moderators and agenda for organizational actions. Emerald Open Research, 2(15), 15. https://doi.org/10.35241/emeraldopenres.13550.1

Henseler, J., \& Fassott, G. (2010). Testing moderating effects in PLS path models: An 
illustration of available procedures Handbook of partial least squares (pp. 713-735): Springer. https://doi.org/10.1007/978-3-540-32827-8_31

Henseler, J., Ringle, C. M., \& Sarstedt, M. (2015). A new criterion for assessing discriminant validity in variance-based structural equation modeling. Journal of the academy of marketing science, 43(1), 115-135. https://doi.org/10.1007/s11747-014-0403-8

Heo, W., Cho, S., \& Lee, P. (2017). How can we know our clients' financial stress? Paper presented at the 2018 Academic Research Colloquium for Financial Planning and Related Disciplines. https://doi.org/10.2139/ssrn.3037527

Hobfoll, S. E. (1989). Conservation of resources: A new attempt at conceptualizing stress. American psychologist, 44(3), 513. https://doi.org/10.1037/0003-066X.44.3.513

Hobfoll, S. E. (2002). Social and psychological resources and adaptation. Review of general psychology, 6(4), 307-324. https://doi.org/10.1037/1089-2680.6.4.307

Hobfoll, S. E., Halbesleben, J., Neveu, J.-P., \& Westman, M. (2018). Conservation of resources in the organizational context: The reality of resources and their consequences. Annual Review of Organizational Psychology and Organizational Behavior, 5, 103-128. https://doi.org/10.1146/annurev-orgpsych-032117-104640

Ilies, R., Pluut, H., \& Aw, S. S. (2015). Studying employee well-being: moving forward. European Journal of Work and Organizational Psychology, 24(6), 848-852. https://doi.org/10.1080/1359432X.2015.1080241

Iqbal, N., Khan, M. M., Mohmand, Y. T., \& Mujtaba, B. G. (2020). The Impact of in-Service Training and Motivation on Job Performance of Technical \& Vocational Education Teachers: Role of Person-Job Fit. Public Organization Review, 20, 529-548. https://doi.org/10.1007/s11115-019-00455-3

Jiang, L., \& Probst, T. M. (2016). A multilevel examination of affective job insecurity climate on safety outcomes. Journal of occupational health psychology, 21(3), 366. https://doi.org/10.1037/ocp0000014

Jiang, Y., \& Wen, J. (2020). Effects of COVID-19 on hotel marketing and management: a perspective article. International Journal of Contemporary Hospitality Management. https://doi.org/10.1108/IJCHM-03-2020-0237

Kasare, K. S. (2020). Effects of coronavirus disease (COVID-19) on Tourism Industry of India. Studies in Indian Place Names, 40(35), 362-365.

Keim, A. C., Landis, R. S., Pierce, C. A., \& Earnest, D. R. (2014). Why do employees worry about their jobs? A meta-analytic review of predictors of job insecurity. Journal of occupational health psychology, 19(3), 269. https://doi.org/10.1037/a0036743

Kim, J., \& Lee, J. C. (2020). Effect of COVID-19 on Preference for Private Dining Facilities in Restaurants. Journal of Hospitality and Tourism Management. https://doi.org/10.1016/j.jhtm.2020.07.008 
Kimura, T., Bande, B., \& Fernandez-Ferrín, P. (2018). Work overload and intimidation: The moderating role of resilience. European Management Journal, 36(6), 736-745. https://doi.org/10.1016/j.emj.2018.03.002

Korman, K., \& Mujtaba, B. G. (2020). Corporate Responses to COVID-19 Layoffs in North America and the Role of Human Resources Departments. Reports Global Health Research, $3(2), 1-17$.

Leka, S., Jain, A., \& Organization, W. H. (2010). Health impact of psychosocial hazards at work: an overview. World Health Organization. Institute of Work, Health \& Organisations, University of Nottingham. Link: https://apps.who.int/iris/handle/10665/44428

Li, S., Wang, Y., Xue, J., Zhao, N., \& Zhu, T. (2020). The impact of COVID-19 epidemic declaration on psychological consequences: a study on active Weibo users. International journal of environmental research and public health, 17(6), 2032. https://doi.org/10.3390/ijerph17062032

Li, W., Yang, Y., Liu, Z.-H., Zhao, Y.-J., Zhang, Q., Zhang, L., \& Xiang, Y.-T. (2020). Progression of mental health services during the COVID-19 outbreak in China. International journal of biological sciences, 16(10), 1732. https://doi.org/10.7150/ijbs.45120

Luthans, F., Avey, J. B., Avolio, B. J., Norman, S. M., \& Combs, G. M. (2006). Psychological capital development: toward a micro-intervention. Journal of Organizational Behavior: The International Journal of Industrial, Occupational and Organizational Psychology and Behavior, 27(3), 387-393. https://doi.org/10.1002/job.373

Luthans, F., Avolio, B. J., Avey, J. B., \& Norman, S. M. (2007). Positive psychological capital: Measurement and relationship with performance and satisfaction. Personnel psychology, 60(3), 541-572. https://doi.org/10.1111/j.1744-6570.2007.00083.x

Markus, H. R., \& Kitayama, S. (1998). The cultural psychology of personality. Journal of cross-cultural psychology, 29(1), 63-87. https://doi.org/10.1177/0022022198291004

Masten, A. S., \& Reed, M.-G. J. (2002). Resilience in development. Handbook of positive psychology, 74, 88 .

McKee-Ryan, F., Song, Z., Wanberg, C. R., \& Kinicki, A. J. (2005). Psychological and physical well-being during unemployment: a meta-analytic study. Journal of applied psychology, 90(1), 53.

Memon, M. A., Cheah, J. H., Ramayah, T., Ting, H., Chuah, F., \& Cham, T. H. (2019). Moderation analysis: issues and guidelines. Journal of Applied Structural Equation Modeling, 3(1), i-xi. https://doi.org/10.47263/JASEM.3(1)01

Moccia, L., Janiri, D., Pepe, M., Dattoli, L., Molinaro, M., De Martin, V., \& Sani, G. (2020). Affective temperament, attachment style, and the psychological impact of the COVID-19 outbreak: an early report on the Italian general population. Brain, behavior, and immunity. https://doi.org/10.1016/j.bbi.2020.04.048 
Morens, D. M., Folkers, G. K., \& Fauci, A. S. (2004). The challenge of emerging and $\begin{array}{llll}\text { re-emerging infectious } & \text { diseases. } & \text { Nature, } 249 .\end{array}$ https://doi.org/10.1038/nature02759

Mujtaba, B. G. (2014). Managerial Skills and Practices for Global Leadership. ILEAD Academy: Florida. ISBN: 978-1-936237-06-7.

Mujtaba, B. G., \& Senathip, T. (2020a). Workplace Mobbing and the Role of Human Resources Management. Business Ethics and Leadership, 4(1), 17-34. https://doi.org/10.4236/jssm.2020.132014

Mujtaba, B. G., \& Senathip, T. (2020b). Layoffs and Downsizing Implications for the Leadership Role of Human Resources. Journal of Service Science and Management, 13(2), 209-228. https://doi.org/10.5296/ijhrs.v10i4.17888

Mujtaba, B. M., Mesa, N. F., McGee, S., Mears, S. O., Moncada, F. S. (2020). Distinctive HR Policies and Practices to Create a Workplace "Where Working Is a Pleasure" amid the Covid-19 Pandemic: The Organizational Culture of Publix Super Markets, Inc. International Journal of Human Resource Studies, 10(4), 125-128. https://doi.org/10.3758/BRM.40.3.879

Mukhtar, P. S. (2020). Mental Wellbeing of Nursing Staff during the COVID-19 Outbreak: A Cultural Perspective. Journal of Emergency Nursing. https://www.ncbi.nlm.nih.gov/pmc/articles/PMC7164897/

Preacher, K. J., \& Hayes, A. F. (2008). Asymptotic and resampling strategies for assessing and comparing indirect effects in multiple mediator models. Behavior research methods, 40(3), 879-891.

Rigdon, E., Becker, J., \& Sarstedt, M. (2017). Equating unobserved conceptual variables and common factors in structural equation models. Working Paper.

Ripp, J., Peccoralo, L., \& Charney, D. (2020). Attending to the emotional well-being of the health care workforce in a New York City health system during the COVID-19 pandemic. Academic Medicine. https://doi.org/10.1097/ACM.0000000000003414

Rubin, G. J., \& Wessely, S. (2020). The psychological effects of quarantining a city. BMJ British Medical Journal, 368. https://doi.org/10.1136/bmj.m313

Ryff, C. D., \& Keyes, C. L. M. (1995). The structure of psychological well-being revisited. $\begin{array}{lllll}\text { Journal of personality and social psychology, } & 69(4), & 719 .\end{array}$ https://doi.org/10.1037/0022-3514.69.4.719

Sarwar, A., Bashir, S., \& Karim, K. A. (2019). Spillover of workplace bullying into family incivility: testing a mediated moderation model in a time-lagged study. Journal of interpersonal violence. https://doi.org/10.1177/0886260519847778

Sarwar, A., \& Muhammad, L. (2020). Impact of employee perceptions of mistreatment on organizational performance in the hotel industry. International Journal of Contemporary Hospitality Management. https://doi.org/10.1108/IJCHM-01-2019-0046 
Sarwar, A., Naseer, S., \& Zhong, J. Y. (2020). Effects of bullying on job insecurity and deviant behaviors in nurses: Roles of resilience and support. Journal of Nursing Management, 28(2), 267-276. https://doi.org/10.1111/jonm.12917

Severson, K., \& Yaffe-Bellany, D. (2020). March 20. Independent Restaurants Brace for the Unknown. The New York Times.

Shmueli, G., Sarstedt, M., Hair, J. F., Cheah, J.-H., Ting, H., Vaithilingam, S., \& Ringle, C. M. (2019). Predictive model assessment in PLS-SEM: guidelines for using PLSpredict. $\begin{array}{llll}\text { European Journal of } & \text { 2322-2347. }\end{array}$ https://doi.org/10.1108/EJM-02-2019-0189

Soelton, M., Amaelia, P., \& Prasetyo, H. (2020). Dealing with job Insecurity, work stress, and family conflict of employees. Paper presented at the 4th International Conference on Management, Economics and Business (ICMEB 2019). https://doi.org/10.2991/aebmr.k.200205.031

Sohrabi, C., Alsafi, Z., O’Neill, N., Khan, M., Kerwan, A., Al-Jabir, A., \& Agha, R. (2020). World Health Organization declares global emergency: A review of the 2019 novel coronavirus (COVID-19). International Journal of Surgery. https://doi.org/10.1016/j.ijsu.2020.02.034

Starrin, B., Åslund, C., \& Nilsson, K. W. (2009). Financial stress, shaming experiences and psychosocial ill-health: studies into the finances-shame model. Social Indicators Research, 91(2), 283-298. https://doi.org/10.1007/s11205-008-9286-8

Sun, W., Wu, M., Qu, P., Lu, C., \& Wang, L. (2014). Psychological well-being of people living with HIV/AIDS under the new epidemic characteristics in China and the risk factors: a population-based study. International Journal of Infectious Diseases, 28, 147-152. https://doi.org/10.1016/j.ijid.2014.07.010

Tran, C. T. H., Tran, H. T. M., Nguyen, H. T. N., Mach, D. N., Phan, H. S. P., Mujtaba, B. G. (July 2020). Stress Management in the Modern Workplace and the Role of Human Resource Professionals. Business Ethics and Leadership, 4(2), 26-40. https://doi.org/10.21272/bel.4(2).26-40.2020

Urbanaviciute, I., Lazauskaite-Zabielske, J., Vander Elst, T., \& De Witte, H. (2018). Qualitative job insecurity and turnover intention. Career Development International, 23(3), 274-290. https://doi.org/10.1108/CDI-07-2017-0117

Van den Broeck, A., Vansteenkiste, M., De Witte, H., \& Lens, W. (2008). Explaining the relationships between job characteristics, burnout, and engagement: The role of basic psychological need satisfaction. Work \& stress, 22(3), 277-294. https://doi.org/10.1080/02678370802393672

Wang, D., Hu, B., Hu, C., Zhu, F., Liu, X., Zhang, J., Xiong, Y. (2020). Clinical characteristics of 138 hospitalized patients with 2019 novel coronavirus-infected pneumonia in Wuhan, China. Jama, 323(11), 1061-1069. https://doi.org/10.1001/jama.2020.1585 


\section{Macrothink}

International Journal of Human Resource Studies

ISSN 2162-3058 2021, Vol. 11, No. 1

Waris, A., Khan, A. U., Ali, M., Ali, A., \& Baset, A. (2020). COVID-19 outbreak: current scenario of Pakistan. New Microbes and New Infections, 100681. https://doi.org/10.1016/j.nmni.2020.100681

Wilson, M. G., Dejoy, D. M., Vandenberg, R. J., Richardson, H. A., \& Mcgrath, A. L. (2004). Work characteristics and employee health and well-being: Test of a model of healthy work organization. Journal of occupational and organizational psychology, 77(4), 565-588. https://doi.org/10.1348/0963179042596522

Youssef, A. B., Zeqiri, A., \& Dedaj, B. (2020). Short and Long Run Effects of COVID-19 on the Hospitality Industry and the Potential Effects on Jet Fuel Markets. IAEE Energy Forum, 1(Covid-19 Issue), 121-124. Link: https://www.iaee.org/en/publications/newsletterdl.aspx?id=906

Zhang, S. X., Wang, Y., Rauch, A., \& Wei, F. (2020). Unprecedented disruption of lives and work: Health, distress and life satisfaction of working adults in China one month into the COVID-19 outbreak. Psychiatry research, 112958. https://doi.org/10.1016/j.psychres.2020.112958

Zheng, X., Zhu, W., Zhao, H., \& Zhang, C. (2015). Employee well-being in organizations: Theoretical model, scale development, and cross-cultural validation. Journal of Organizational Behavior, 36(5), 621-644. https://doi.org/10.1002/job.1990

\section{Copyright Disclaimer}

Copyright for this article is retained by the author(s), with first publication rights granted to the journal.

This is an open-access article distributed under the terms and conditions of the Creative Commons Attribution license (http://creativecommons.org/licenses/by/4.0/). 